\title{
ATTRACTTION OF BARK BEETLES (COLEOPTERA: SCOLYTIDAE) TO NORWAY SPRUCE IN TIMBERLINE FOREST IN TATRA MOUNTAINS, WEST CARPATHIANS
}

\author{
Peter Zach ${ }^{1}$, Branislav Kršiak ${ }^{1}$, Ján Kulfan ${ }^{1}$, Milada Holecová ${ }^{2}$ \\ ${ }^{1}$ Institute of Forest Ecology, Slovak Academy of Sciences, Štúrova 2, SK - 96053 Zvolen \\ ${ }^{2}$ Comenius University, Faculty of Natural Sciences, Deparment of Zoology, \\ Mlynská dolina B1, SK - 84215 Bratislava
}

Zach P., KrŠIAK B., Kulfan J., Holecová M.: Attracttion of bark beetles (Coleoptera: Scolytidae) to Norway spruce in timberline forest in Tatra Mountains, West Carpathians. Lesn. Čas. - Forestry Journal, 56(3): 285 - 293, 2010, tab. 2, ref. 21. Original paper. ISSN $0323-10468$

Attraction of bark beetles (Coleoptera: Scolytidae) to Norway spruce was studied in the timberline forest in Tatra Mountains, West Carpathians, Central Europe, by trapping bark beetles in flight interception traps fixed to the lower parts of the 18 trunks of spruce trees, and by recording colonizations of bark beetles on those trees in 2004 . The trees were devoid of needles in the upper crown (1/4 up to $1 / 3$ of the tree top dead) and were growing in three distant sample plots. Each plot was representing three different situations (biotopes) in the timberline spruce forest - forest, forest line and tree line, in altitudes between $1,280-1,560 \mathrm{~m}$. A total of 18 traps yielded a total of 5,015 individuals and 19 bark beetle species associated with spruce, the five of which, Phtorophloeus spinulosus, Xyloterus lineatus, Pityophthorus pityographus, Pityogenes chalcographus, Ips typographus, were also documented to be developing in the the studied trees. Traps in the forest line yielded more individuals of bark beetles (all species considered together) than those in the forest and the tree line, although this was not significant $(\mathrm{P}>0.05, \mathrm{~K}-\mathrm{W}$ Anova). The bark beetle assemblages showed very low dissimilarity in their structure between the forest and forest line, however, the assemblages in these two situations, aparently, differed from the assemblage in the tree line. Over the period $2004-2008$ three $(16.7 \%)$ of the 18 studied trees died. All documented cases of the tree mortality were associated with colonization by I. typographus.

Key words: Picea abies, Scolytidae, Ips typographus, mountain forest

Príspevok sumarizuje výsledky výskumu atraktivity 18 chradnúcich dospelých jedincov smreka (Picea abies) pre podkôrnikovité chrobáky (Coleoptera: Scolytidae) v oblasti hornej hranice lesa v Tatrách v roku 2004 a zároveň hodnotí prežívanie týchto smrekov v rokoch 2004-2008. Do chemicky nevnadených nárazových lapačov umiestnených na kmeňoch predmetných smrekov bolo odchytených spolu 5015 jedincov a 19 druhov podkôrnikovitých vývinom viazaných na smrek. Najviac 
jedincov podkôrnikovitých (všetky druhy hodnotené spolu) bolo získaných z lapačov na smrekoch rastúcich na hranici, resp. v okraji súvislého smrekového lesa, menej z lapačov v smrekovom lese pod touto hranicou a najmenej z lapačov v oblasti jednotlivého výskytu smreka v pásme vysokohorských lúk a kosodreviny. Dva sledované jedince smreka odumreli v roku 2004, jeden jedinec odumrel v roku 2007. Všetky tri prípady odumretia smreka $(16,7 \%, \mathrm{n}=18)$ súviseli s úspešnou kolonizáciou smrekov lykožrútom smrekovým.

Klúčové slová: smrek obyčajný, podkôrnikovité, lykožrút smrekový, horský les

\section{Introduction}

Bark beetles (Coleoptera: Scolytidae), at least some species among them, e.g. Ips typographus (L.), play a crucial role in the dynamics of Norway spruce forests in Europe (ChristiansEN \& BAKKE 1988). The role of particular bark beetle species in modifying the structure of natural spruce forests in West Carpathians, Central Europe, has been well recognized (PFeFFer 1955, Stolina 1969a,b).

Local outbreaks of the bark beetle Ips typographus associated with the decline of mountain spruce forests in Tatra Mountains in 2004 (e.g. in Bielovodská, Javorová and Velická dolina (valley)) were the reason to study Norway spruce (Picea abies (L.) Karsten) and its bark beetle associates in the remote areas of the timberline forest.

This study focuses on the attraction of bark beetles to mature spruce in the timberline forest in Tatra Mountains. The questions addressed are the following: (1) what bark beetle species are attracted or supposed to be attracted to mature spruce devoid of needles in the upper crown?, (2) do such trees growing in different situations (biotopes) in the timberline forest attract different bark beetle fauna?, (3) what is the magnitude of the spruce mortality associated with the occurrence of bark beetles in the timberline forest?

\section{Materials and methods}

\subsection{Study area, sample plots}

The study was carried out in natural spruce forests (nature reserves) in Tatra Mountains, Tatra National Park, West Carpathians, Central Europe, in three separate sample plots in Tomanova $(1,280-1,360 \mathrm{~m})$, Velická $(1,460-1,520 \mathrm{~m})$ and Bielovodská dolina (valley) $(1,360-1,560 \mathrm{~m}$ a.s.l.). Each sample plot is characterized by three different situations (biotopes) on altitudinal gradient: 1. Forest (spruce forest, canopy cover 80\%), 2. forest line (upper margin of spruce forest, canopy cover $70-80 \%$ ), 3. tree line (the uppermost limit of occurrence of spruce, open biotope with scattered spruce trees). Situation 1 and 2 both are characterized by a Norway spruce-dominated forest where the proportion of spruce is as high as 95\%, and where the other tree species like rowan (Sorbus aucuparia Linnaeus), Scots pine (Pinus sylvestris Linnaeus), dwarf pine (Pinus mugo Turra), Arola pine (Pinus cembra Linnaeus) and willow species (Salix spp.) share the rest 5\%. Patches of dwarf pine and mountain (alpine) meadows are typical for situation 3. Forest structure is modified by bedrock, rocky soils, strong winds, avalanches, cool climate, tree competition and bark beetles, of which Ips typographus is most important.

\subsection{Sampling bark beetles}

Bark beetles were sampled by the window flight trapping in 2004. A total of 6 flight interception (window) traps were set for bark beetles in each sample plot. Traps were fixed to mature spruce trees (for 
tree description see below) at the heights of 1.3-1.6m, measured from the ground to the lower margin of trap panes (for tree description see below). In each sample plot they were positioned on two vertical transects which were approximately $200 \mathrm{~m}$ distant. Each transect was represented by the three situations (biotopes) characterized above. Traps constituted two transparent acrylic panes $(0.60 \times 0.40 \mathrm{~m}$ each $)$ crossed at right angles, a circular dark green funnel (diameter $0.4 \mathrm{~m}$ ) placed below the panes, and a collector containing water, coarse salt $(\mathrm{NaCl})$ and few drops of detergent to reduce surface tension of water solution in collectors. They were emptied over the period 15th May - 30th September 2004, at the end of each month. In the laboratory, bark beetles were separated from the fragments of organic material (e.g. bark, twigs, lichens, other invertebrates, etc.), and then placed in vials containing $70 \%$ ethanol.

Bark beetles were identified according to PFEFFER $(1989,1995)$.

\subsection{Monitoring tree mortality}

A total of 18 mature spruce trees holding traps in 2004 were monitored with focus on their mortality over the period May 2004 to August 2008. The trees were $0.4-0.5 \mathrm{~m}$ thick at breast height $\left(\mathrm{d}_{1.3}\right)$ and devoid of needles (reason unknown) in the upper crown (1/4 up to $1 / 3$ of the tree top dead in 2004). In 2004 bark beetles were recorded in the lower trunks and lower branches of all monitored trees (up to the height of $3 \mathrm{~m}$, measured from the ground) by entrance or exit holes produced by adults specimens of bark beetles, or by larval galleries if conditions (e.g. loose bark) allowed this (in the study area mechanical damage to trees by man is strictly prohibited by nature conservation). Later on (2005-2008) the occurrence of bark beetles was only noticed in those monitored trees, which had died.

\subsection{Data analysis}

Hierarchical classification (cluster analysis, complete linkage, Wishart's coefficient of dissimilarity) in the program Syntax (PoDANI 2001) was used to compare the structure of bark beetle assemblages among the forest, forest line and tree line. Log-transformed data (pooled number of bark beetles caught over the study period) were used for the comparison. Testing for the differences in the yearly catches

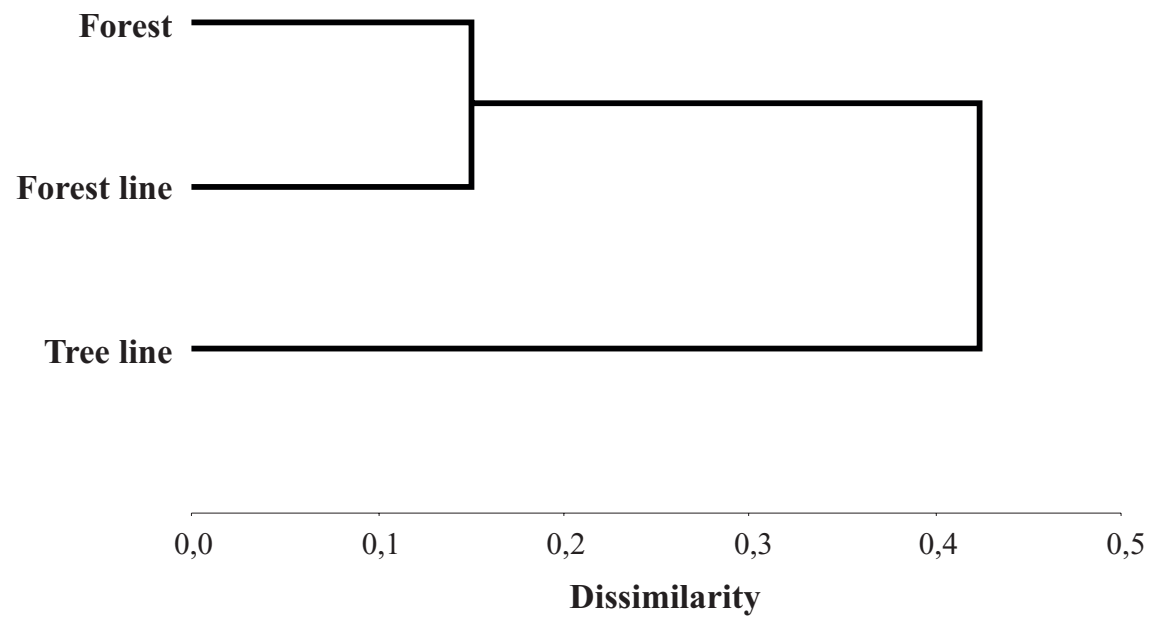

Fig. 1. Comparison among the bark beetle assemblage structure in traps fixed to mature spruce trees in the forest, forest line and tree line. Hierarchical classification, cluster analysis, complete linkage, Wishart's coefficient of dissimilarity. Data from a total of 18 traps, six traps set in each situation. Tatra Mountains, 2004. 


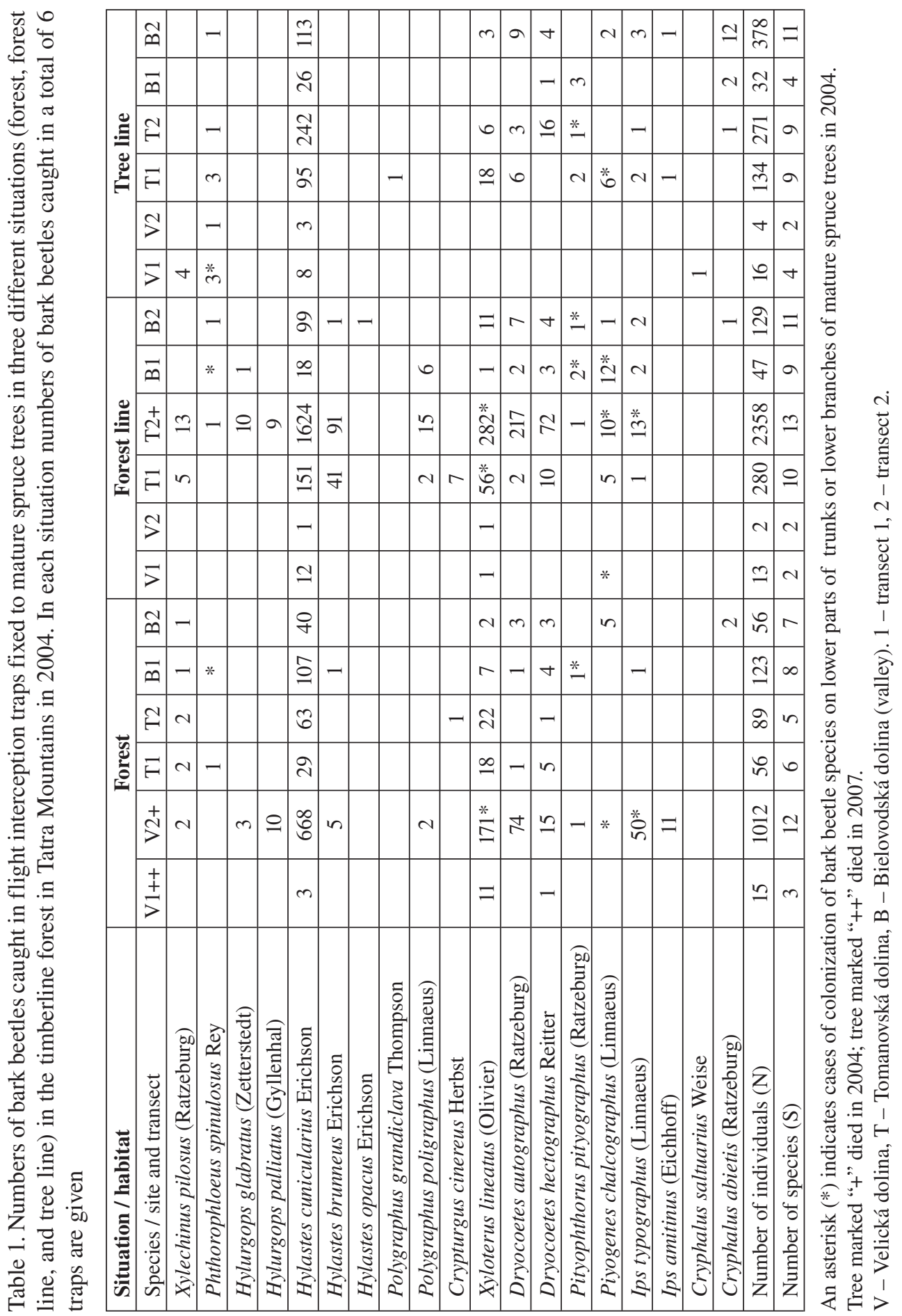


of bark beetles among particular situations was performed by Kruskal-Wallis Anova (SoKAL \& RoHLF 2000). This non-parametric test was made separately for all bark beetle individuals recorded, and the two predominant scolytid species Hylastes cunicularius Erichson and Xyloterus lineatus (Olivier). Computations were made in the programme Statistica (StatSoft Inc. 2005).

\section{Results}

The 18 traps set in three different situations (biotopes) in the timberline forest in Tatra Mountains in 2004 yielded a total of 5,015 individuals and 19 species of bark beetles associated with spruce (Tab. 1). Most individuals (all 19 species considered together) were caught in the forest line (56.4\%), followed by the forest $(26.9 \%)$ and the tree line $(16.7 \%)$. Number of species recorded was equal in the forest and forest line (16 species and $80 \%$ of all species recorded) and slightly lower in the tree line (13 species and $70 \%$ of all species recorded). Predominant species (dominance of abundance over 10\%) were represented by Hylastes cunicularius (all situations), Xyloterus lineatus (forest and forest line) and Pityophthorus pityographus (Ratzburg) (tree line). In addition to bark beetle species listed in Table 1, two specimens of Pityogenes conjunctus (Reitter), the species not associated with spruce, were also recorded.

The bark beetle assemblages showed very low dissimilarity in their structure between the forest and forest line, however, the assemblages in these two situations differed from the assemblage in the tree line (Fig. 1).

The number of bark beetles caught (all species together) showed a great deal of variability within the forest, forest line and tree line (Tab. 1). It did not differ significantly among these situations $(\mathrm{H}(2, \mathrm{~N}=18)=0.035, \mathrm{P}=0.983, \mathrm{~K}-\mathrm{W}$ Anova $)$, and the same was true for the two predominating scolytid species, Hylastes cunicularius $(\mathrm{H}(2, \mathrm{~N}=18)=0.073, \mathrm{P}=0.964, \mathrm{~K}-\mathrm{W}$ Anova $)$ and Xyloterus lineatus $(\mathrm{H}(2, \mathrm{~N}=18)$ $=4.263, \mathrm{P}=0.119, \mathrm{~K}-\mathrm{W}$ Anova).

Some of the 18 studied spruce trees were found to be colonized by Phtorophloeus spinulosus Rey (branches), Xyloterus lineatus (trunks), Pityophthorus pityographus (branches), Pityogenes chalcographhus (branches) and Ips typographus (trunks) (Tab. 1).

Three of the 18 studied trees (16.7\%) died over the period $2004-2008$. Two trees died in the forest, one tree died in the forest line. All documented cases of the tree mortality were associated with colonizations by Ips typographus.

4. Discussion

Norway spruce in Central Europe has a species-rich bark beetle fauna (PFEFFER 1955, 1989, 1995 Zumr 1984, Kula \& ZabeCKi 2000, 2002). The species list in Table 1 includes approximately two-thirds of the known bark beetle associates of spruce in West Carpathians (PFEFFER 1955, 1989). Most species recorded in this study are commom associates of spruce. The record of a single specimen of Polygraphus grandiclava Thompson (Tomanovská dolina (valley), tree line, Tab. 1) is worth noticing. In the mountain spruce forests in Tatra Mountains, this wide polyphage - host plants include the representatives of Pinaceae and Rosaceae (PFefFer 1955, 1995, Avtzis et al. 2008), is developing in Arola pine, spruce and, possibly, in dwarf pine too. It is collected only rarely. The occurrence of $P$. grandiclava in the tree line is documenting a broad 
ecological plasticity in the beetle spread from the lowlands to the uppermost limit of its distribution in West Carpathians. The scolytid Pityogenes conjunctus (not listed in Tab. 1) should also be mentioned here in more detail. The beetle is typical for the timberline forest where it is developing in dwarf pine and Arola pine (PFEFFER 1955). Two specimens of $P$. conjunctus (Tomanovská and Bielovodská dolina (valley), tree line), highly likely, were caught by accident. In Tatra Mountains, T. conjunctus seems to be more frequent and abundant than $P$. gradiclava.

In spruce forests, and especially in forest margins, more bark beetles are expected than at sites where a few trees occur. The timberline forest with a high or relatively high density of trees (e.g. forest and forest line) provides more resources for bark beetles than environments characterized by a few scattered trees (e.g. tree line in this study). Such trees in the tree line, moreover, are more exposed than those in dense forest structures, much less sheltered and thus less protected against strong wind currents which may affect the occurrence of bark beetles. Despite this, a large number of bark beetle individuals and species may be attracted to certain individuals of singly growing trees in the tree line (Tab. 1).

In Table 1 bark beetle species are listed by particular situation in the timberline forest, as they were caught in 2004. Numbers of bark beetles sampled reflect, first, the attraction (affinity) of bark beetle species to each of the 18 spruce trees and, second, the abundance and/or activity of bark beetle species in the given situation. Great deal of variability in the number of bark beetles (all species) sampled in the forest $(5-1,012)$, forest line $(2-2,358)$ and tree line $(4-379$ individuals, Tab. 1) might indicate that the attraction (affinity) of bark beetles to particular trees differs a lot within each of those three situations, meaning that particular trees in particular situations, highly likely, have remarkably different attractivity for bark beetles.

Hierarchical classification (Fig. 1), in addition to differences in species composition, reflects the lower number of bark beetles sampled in the tree line compared to that gathered in the forest line and forest, although this is not significant based on the sample evidence (low median numbers of bark beetles caught in all situations). The study design employed here is not a robust one. It does not allow to separate between the effect of ,attraction“ and that of ,accidental trapping“ on the occurence of bark beetles in traps. High catches of certain bark beetle species in traps, undoubtedly, have much to do with ,,attraction to trees and/or tree attractivity“ but there is some uncertainty about this as some bark beetle species not attracted to the trees may also be caught in traps, especially in areas or situations where their populations are high.

Surprisingly, the bark beetle Hylastes cunicularius highly predominated in samples from all situations, however, its development in the studied trees was not recorded (Tab. 1). In natural spruce forests in the study area, the beetle is widespread and abundant everywhere where the wind-felling and avalanches regularly modify the forest structure, providing the beetle with a supply of breeding material in the form of spruce roots, stumps and, less frequently, spruce logs well-touching (penetrating) the soil surface. The beetle is known to aggregate near suitable resources and at the beetles of its own species which have located such resources (EIDMANN \& KULA \& LindeLöw 1991). Ex- 
periments showed a positive response of the beetle to mechanical damage (cuts) on pine logs (EIDMANN \& KULA \& Lindelöw 1991). In the study area, avellanches, tree, ice and rock fall are responsible for the frequent occurrence of wounds on the base of the trunks of the studied (monitored) trees which might attract individuals of the beetle showing a positive response to ethanol (SCHROEDER \& LINDELÖw 1989), a product of microbial processes. In this study, low positioned traps could caught individuals flying to the trees low above the ground. Similarly, $H$. cunicularius was shown to be a highly predominant scolytid in the wind-felled forest in the Alps (WERMELINGER \& DUELLI \& OBRIST 2002).

Two scolytid species, Hylurgops palliatus (Gyllenhal) and Hylurgops glabratus (Zetterstedt), were caught in the forest and forest line but not in the tree line. Attack densities of $H$. palliatus on spruce bolts increase markedly from the forest clearcutedge towards the forest interior (Peltonen \& HeliövaARA 1999); in H. glabratus similar pattern of habitat preference may be expected. Also, Dryocoetes autographus (Ratzeburg) and Dryocoetes hectographus Reitter, based on their catches in traps, tended to be more in the forest and forest line than in the tree line. None of them was found to be developing in the studied trees in 2004.

The bark beetle Ips amitinus (Eichhof.) is frequent and abundant in mountain spruce forests in Tatra Mountains. Preference of the beetle for the upper parts of the spruce trunks (ZumR 1984) may explain its infrequent and low occurrence in traps (Tab. 1). The beetle was not recorded in the forest line by the flight window trapping (Fig. 1), athough it was present there (P. Zach, personal observation). This calls for a more robust study design based on more replicates (traps) in the lower, but also in the middle and upper parts of the spruce trunks.

Five (26.3\%) of the 19 bark beetle associates of spruce in this study were documented to be developing in the lower parts of the trunks and/or in the lower branches of the studied trees in 2004. The cases of development of certain bark beetle species in particular trees are marked with an asterisk attached to the number of bark beetle individuals caught (Tab. 1). Two scolytid species, P. spinulosus and P. chalcographus, were not always caught in the traps fixed to the trees in which they were developing. Such cases are marked with an asterisk only.

Tree death is an ecological process (FrankLin \& ShUGart \& Harmon 1987). As evident, in the timberline forest in Tatra Mountains a good number of individuals and species of bark beetles are attracted or supposed to be attracted to mature spruce devoid of needles in the upper crown. Such trees, often classified as dying and not healthy, are typical for the timberline forests in Central Europe. Based on our knowledge, they can live over a long period of time if not wind-felled, damaged by avallanches or successfully attacked by I. typographus and pathogenic fungi. In 2004 bark beetles were sampled in areas where I. typographus outbreaked (Bielovodská and Velická dolina (valley)), or where its population was retaining low (Tomanovská dolina (valley)). I. typographus was found to attack and kill the two trees holding the traps yielding its highest catch (forest, tree V2 - 50 individuals; forest line, tree T2 - and 13 individuals of I. typographus, Tab. 1). Its local outbreak in Velická dolina (valley) led to 
numerous cases of spruce death over the summer 2004 and later on $(2005$ - 2008). In Velická dolina (valley) another tree (tree V1, Tab. 1) died in 2007 due to the attack by the beetle. In this study, only those of the studied trees died which were colonized by I. typographus. This agrees with the observations by HEDGREN (2004) who found experimentally that the mortality of spruce is strongly related to the presence of $I$. typographus and less to the presence of $P$. chalcographus.

A highly excessive wind disturbance in Tatra Mountains, dated 19th November 2004 (KoREŇ 2005, ZACH et al. 2007), has resulted in the outbreak of Ips typographus also in Tichá dolina (valley), the area adjacent to Tomanovská dolina (valley). The present outbreak of I. typographus in the mountain area is expected to accelerate the mortality of mature spruce trees in the timberline forest.

\section{Acknowledgements}

This publication is the result of the project implementation (project Centre of Excellence of Biological Methods of Forest Protection, coded ITMS 26220120008), supported by the Research \& Development Operational Programme funded by the ERDF.

The State Forests of Tatra Mts. National Park and the Administration of Tatra Mts. National Park provided administrative support to field studies. P. Tuček (Institute of Forest Ecology, Slovak Academy of Sciences) assisted with beetle collections and separation.

\section{References}

1. Avtzis D., Knížek M., Hellrigl K., Staufer Ch., 2008: Polygraphus grandiclava (Coleoptera: Curculionidae) collected from pine and cherry trees: A phylogenetic analysis. Eur. J. Entomol., 105, p. 789-792. - 2. Christiansen E., BAKKe A., 1988: The spruce bark beetle of Eurasia, p. 479-503. In Berryman A. A.: Dynamics of Forest Insects Populations. Patterns, Causes, Implications. Plenum Press, New York and London, 603 pp. - 3. Eidmann H.H., Kula E., Lindelöw A., 1991: Host recognition and aggregation behaviour of Hylastes cunicularius Erichson (Col., Scolytidae) in the laboratory. J. Appl. Ent., 112, p. 11-18. - 4. Franklin J. F., Shugart H. H., Harmon M. E., 1987: Tree death as an ecological process. The causes, consequences and variability of tree mortality. BioScience, 37, p. 550-556. - 5. Hedgren P. O., 2004: The bark beetle Pityogenes chalcographus (L.) (Scolytidae) in living trees: reproductive success, tree mortality and interaction with Ips typographus. J. Appl. Ent., 128, p. 161-166. - 6. Koreñ M., 2005: Vetrová kalamita 19. novembra 2004: nové pohlady a konsekvencie. Tatry, XLIV, mimoriadne vydanie, s. 7-28. - 6. KULA E., ZABECKI W., 2000: Atraktivita smrku pro kambioxylofágy v některých souborech lesních typů. Journal of Forest Science, 46(5): 217-225. - 7. KULA E., ZABECKI W., 2002: Struktura kambioxylofágní fauny smrku rezervace Kněhyně a hospodářských smrkových porostů v Moravskoslezkých Beskydech. Čas. Slez. Muz. Opava, 51, p. 155-164. - 8. Peltonen M., HeliövaArA K., 1999: Attak density and breeding success of bark beetles (Coleoptera, Scolytidae) at different distances from forest-clearcut adge. Agricultural and Forest Entomology, 1, p. 237-242. - 9. PFefrer A., 1955: Fauna ČSR 6. Kůrovci - Scolytoidea. Praha: Nakl. ČSAV, 324 pp. - 10. Pfeffer A., 1989: Kůrovcovití (Scolytidae) a jádrohlodovití (Platypodidae). Zoologické klíče, Praha: Academia, 137 pp. - 11. Pfeffer A., 1995: Zentral - und westpaläarktische Borken - und Kernkäfer. (Coleoptera: Scolytidae, Platypodidae). Pro Entomologia, Basel, 310 pp. - 12. PodAnI J., 2001: Syn-tax 2000. Computer programs for data analysis in ecology and systematics. User's manual. Budapest: Scientia publishing, 53 pp. - 13. SoKal R.R., Rohlf F. J., 2000: Biometry: the principles and practice of statistics in biological research. Sixth printing. W. H. Freeman and company, New York, 887 pp. - 14. Schroeder L., M., Lindelöw, 1989: Attraction of scolytids and associated beetles by different absolute amounts and proportions of -pinene 
and ethanol. Journal of Chemical Ecology, 15(3): 807-817. - 15. STATSoft, Inc. 2005. STATISTICA (data analysis software system), version 7.1. - 16. Stolina M., 1969a: Der Einfluss der Ipidenfauna auf die Entwicklung der Struktur von Naturwäldern in den Westkarpaten. Schweizerische Zeitschrift für Forstwesen, 120(11): 610-627. - 17. Stolina M., 1969b: Vplyv Ipidofauny na vývoj štruktúry prírodných horských lesov v západných Karpatoch. Lesnícky časopis, 15(1): 45-63. - 18. Wermelinger B., Duelui P., OBRIST M.K., 2002: Dynamics of saproxylic beetles (Coleoptera) in windthrow areas in alpine spruce forests. For. Snow Landsc. Res., 77(1/2): 133-148. - 19. ZaCh P., KRŠIAK B., Kulfan J., Vargová K., 2007: Observations on beetles (Coleoptera) and moth larvae (Lepidoptera) after excessive wind disturbance in the Tatra Mountains, p. 56. In Lingua, E., Marzano R (eds.): Natural Hazards and Natural Disturbances in Mountain Forests - Challenges and Opportunities for Silviculture. An International Conference of the IUFRO, Trento, Italy, September 18-21, 90 pp. - 20. ZumR V., 1984: Prostorové rozmístnění kůrovců (Coleoptera, Scolytidae) na smrku ztepilém (Picea excelsa L.) a jejich indiference podle lesních vegetačních stupňù. Lesnictví, 30, p. 509-522. - 21. ZumR V., 1985: Biologie a ekologie lýkožrouta smrkového (Ips typographus) a ochrana proti němu. Praha: Academia Nakl. ČSAV, 95 pp.

\section{Resumé}

V oblasti hornej hranice smrekového lesa v Tatrách (Tomanovská, Velická a Bielovodská dolina) bola od polovice mája do konca septembra 2004 študovaná atraktivita 18 dospelých smrekov pre podkôrnikovité chrobáky (Coleoptera: Scolytidae). Smreky mali odumretú jednu štvrtinu až jednu tretinu koruny (odumretá vrcholová čast') a ich prežívanie bolo monitorované do konca augusta 2008 v troch rôznych biotopoch: smrekový les, hranica súvislého smrekového lesa, hranica výskytu jedincov smreka. Na kmene smrekov vo výške 1,3-1,6m nad úrovňou terénu boli upevnené chemicky nevnadené a pre chrobáky farebne neatraktívne lapače. Tieto odchytili spolu 5015 jedincov a 19 druhov podkôrnikovitých vývinom viazaných na smrek (tab. 1) a dva jedince lykožrúta Pityogenes conjunctus žijúceho na borovici horskej (kosodrevine) a borovici limbovej (limbe). V odchytoch vysoko prevládal lykokaz sadenicový (Hylastes cunicularius); odchyty lykožrúta smrekového (Ips typographus) boli nízke. Najviac jedincov podkôrnikovitých (všetky druhy spolu) bolo odchytených na smrekoch rastúcich na hranici (v okraji) súvislého smrekového lesa, menej v smrekovom lese pod touto hranicou a najmenej v oblasti jednotlivého výskytu smreka v zóne vysokohorských lúk a kosodreviny (tab. 1), no rozdiely neboli štatisticky významné (P>0.05, K-W Anova). Abundančná štruktúra fauny podkôrnikovitých v porovnávaných biotopoch bola iba málo, resp. relatívne málo nepodobná (obr. 1). Odchyty odrážajú atraktivitu spodnej časti kmeňa smrekov pre podkôrnikovité a tiež početnost a pohybovú aktivitu podkôrnikovitých. V spodnej časti kmeňa študovaných smrekov bol dokumentovaný vývin Phtorophloeus spinulosus (konáre), Xyloterus lineatus (kmeň), Pityophthorus pityographus (konáre), Pityogenes chalcographhus (konáre) and Ips typographus (kmeň). Dva zo sledovaných smrekov odumreli v roku 2004, další v roku 2007. Všetky tri prípady odumretia smreka $(16.7 \%, \mathrm{n}=18)$ súviseli s úspešným osídlením lykožrútom smrekovým. Zo sledovaných jednotlivo rastúcich smrekov v pásme borovice horskej a vysokohorských lúk neodumrel počas výskumu žiadny. Očakávame, že súčasné premnoženie lykožrúta smrekového v Tatrách urýchli odumieranie dospelých smrekov a ich porastov v oblasti hornej hranice lesa. 